ISSN 0772-084X

\title{
Afrika Focus
}

Vol. 14, Nr. 2, 1998

Tijdschrift van AFRIKA BRUG v.z.w.

Periodical of the association AFRIKA BRUG

Périodique d'AFRIKA BRUG a.s.b.l.

Stichtende organisatie:

Afrika Vereniging van de Rijksuniversiteit Gent (1985)

Founding organisation:

Africa Association of the State University of Ghent, Belgium (1985)

Organisation fondatrice :

Association Afrique de l'Université de Gand (1985) 


\section{Eindredactie / Final Editing / Rédaction définitive}

\section{Dirk Beke (RUG \& RUCA)}

\section{Afrika Focus wordt uitgegeven met de steun van het Afrika Instituut (Brussel)}

Afrika Focus is published with the support of the Africa Institute (Brussels)

Afrika Focus est publié avec le soutien de l'Institut africain (Bruxelles) 